\title{
Transforming Romanian school buildings in prosumers. An opportunity for increasing the energy efficiency in electrical networks and reducing the environmental impact of the power distribution sector
}

\author{
Mircea Scripcariu ${ }^{1 *}$, Cristian Gheorghiu ${ }^{2}$, Ioan-Sevastian Bitir-Istrate ${ }^{3}$ and Mihaela- \\ Madalina Bonea $^{4}$ \\ ${ }^{1}$ Associate Prof., Dept. of Energy Production and Use, University POLITEHNICA of Bucharest, \\ Romania \\ ${ }^{2} \mathrm{PhD}$. Student, Dept. of Energy Production and Use, University POLITEHNICA of Bucharest, \\ Romania \\ ${ }^{3}$ Lecturer, Dept. of Energy Production and Use, University POLITEHNICA of Bucharest, Romania \\ ${ }^{4}$ Master Degree Student, Dept. of Energy Production and Use, University POLITEHNICA of \\ Bucharest, Romania
}

\begin{abstract}
In the last decades, electricity systems suffer crucial transformations from integrated networks with a unidirectional flow, to decentralized, bidirectional flow networks. The stakeholders of this largescale business have changed or improved their role. Electricity distribution companies are becoming service providers and end-users are becoming electricity producers. With the legislation issued in 2018, a new stakeholder was born on the Romanian electricity market, the prosumer. So, the decentralization reached an extreme by giving the smallest end-user the opportunity to become an electricity producer. In the first paragraph of this paper, authors summarize provisions of most recent energy strategies issued by the Romanian Government and the regulatory framework for incentivizing this market player. Given the growing interest of local administration in energy efficiency and pollution reduction, authors consider that schools can play a major role in fulfilling ambitious environmental targets. Most school buildings date from the communist regime and have a rather similar design. In their energy management programmes, municipalities consider energy efficiency in school buildings and authors present the case study of a school in the city of Ploiesti, one of the largest in southern Romania. A brief description of the electricity enduse systems is presented. Before any measure is taken on the supply-side, school's administration needs to implement the demand-side measures. Next, these measures are investigated, and the results of the technicaleconomic analysis are presented. In southern Romania, photovoltaic (PV) solutions have better operating conditions and for this case study the solution for local generation with PV panels is presented. In the paper, authors are making an in-depth investigation of extending the prosumers
\end{abstract}

*Corresponding author : mirceas1960@yahoo.com 
model, with local PV generation on school buildings, over most of Romanian geographical regions. The carbon footprint is calculated, and the environmental benefits of this integrated approach are highlighted.

\section{Strategical options and Regulatory Framework for Prosumers}

The transition towards clean energy is essential in the fight against climate change. Economic performance and global geopolitical relationship are modelled by the energy sector, thus making the monitoring and understanding the past and future determining factors of electricity prices and costs an extremely important action. Each effort to improve the environmental impact counts. Modern electricity systems are switching from a unidirectional energy flow to a bi-directional one and from electricity supply to complex services. In this framework, modern renewable electricity generation technologies have continuously improved their economical performances allowing the smallest consumer to become a "prosumer", i.e. an active player in the electricity market. This opportunity will stimulate end-users to actively participate to the reduction of world's carbon footprint.

As per the Romanian legislation [1], the prosumer is the end-user which simultaneously uses, produces, stores and can sell electricity produced from Renewable Energy Sources (RES). As [2] points out, the prosumer can optimize the power demand and respectively the power injection in the local grid, thus flattening the global power demand curve and reducing the network balancing costs.

The main objectives of [1] are to develop the RES integration capacity and mechanisms into the National Power Grid, to encourage the transition from consumer to prosumer for residential, industrial, agricultural and public entities, on par with the development of smart metering systems, thus leading to the development of a nation-wide Smart Grid. The maximum installed capacity in prosumers is set to reach $750 \mathrm{MW}$ by 2030 in the European Union alone.

The European Union, by it's RES support Directive (CE 2016b), states that the prosumer transition should be encouraged by a feed-in-tariff scheme, offering financing and grants, and by modifying the fiscal legislation in order to ensure the bi-directional transactions economic compensations between the prosumers and the Distribution System Operators (DSO).

DSO's must also continue the refurbishment process of their grids, while considering the target to develop the Smart Grid concept and ensuring the real-time interactions with the existing and future prosumers.

In the European Union, the prosumers are divided into [3]: residential prosumers which produce electricity by photovoltaic systems - residential associations, foundations, or other civil entities with no lucrative purpose which only produce electricity to cover their own needs, commercial prosumers - small and medium enterprises (SME), universal stores, office buildings and other similar sites which are defined by a different main activity (NACE Code) than electricity production and public prosumers - schools, hospitals and other public institutions which can generate electricity.

In this paper, the public prosumer sector will be in-depth analysed, as densely populated urban areas have a significant energy economy potential and represent an optimal platform for environmental impact reduction, as Rotterdam has already proven [4] by implementing the urban symbiosis concept (see Figure 1). This notion has also been implemented, by the EU Celsius Cities Project to test the smart energy planning in Köln, Genova, Göteborg and London. 


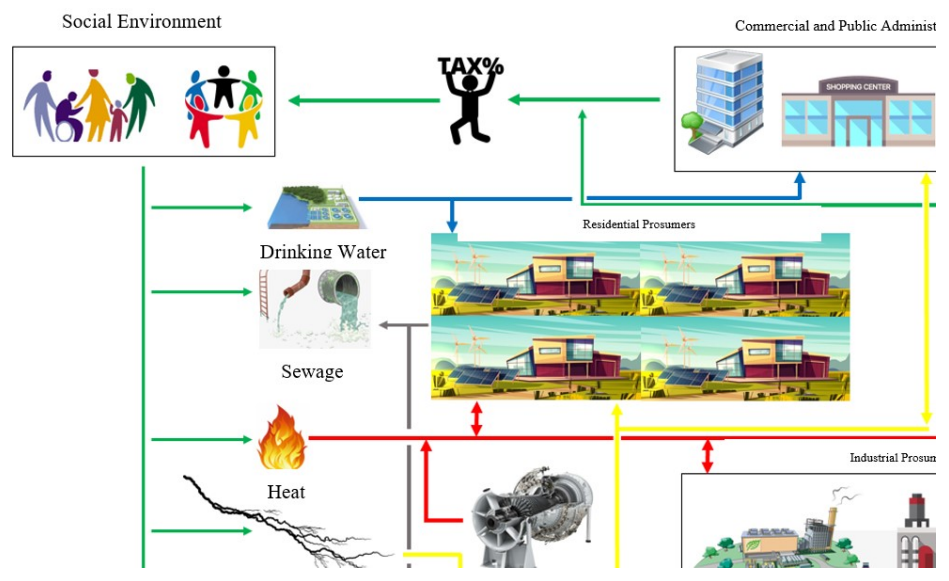

Fig. 1. Urban symbiosis concept where taxes (green), drinking water (blue), heat (red), power (yellow) and services / production (grey) sectors function as a whole, reusing and thus increasing the efficiency of energy use

The Romanian legislation [1] states that a prosumer which has an installed capacity of $27 \mathrm{~kW}$ or under is entitled to sell the electricity produced and injected into the power grid to the energy suppliers with which they have an ongoing energy supply contract. The legislation also states that Public Authorities which have an installed capacity of $3 \mathrm{MW}$ or under, financed partially or fully from structural funds and which don't have an "income generator" status can also sell the produced electricity in the power grid by means of bilateral contracting. However, at this moment, the Romanian legislation does not provide the possibility for the prosumer to sell energy on the market, at a competitive price as it only allows the compensation of the energy injected in the network at a yearly regulated price, set as the average daily closing price of the market for the previous year.

In order to evaluate the potential of public prosumers, this paper will analyse the Romanian school building sub-sector. In Section 2, the project development potential represented by Romania's school-building sub-sector will be investigated, with a case-study of a relevant school. The technic and economic impact of the development of such public prosumers, starting from the case study presented and extrapolating for all the similar sites in Romania will be also presented. In Section 3, a brief review for possible funding sources will pe presented, while in Section 4 the main conclusions and the future work needed will be presented.

\section{Technic and economic analysis for a national programme}

The paper based its analysis on a case study represented by a school located in one of the largest cities in Romania, Ploiesti, in the southern part of the country. "Grigore Moisil" primary school, was part of a project in which several Romanian primary schools were selected for building gym halls - new buildings, out of the main building. Throughout Romania, 726 primary schools out of the total of 3,039 existing primary schools took part in the Gym Hall building project which took place between 2008 - 2012 and was coordinated by the Ministry of Development and was funded by the Ministry of Development and by the National Investment Company.

The first stage of the analysis consisted in an energy performance benchmarking for the energy boundary of the Grigore Moisil Primary school. As of March 2020, no school in Romania is engaged in pro-active energy efficiency by the means of drafting up a yearly 
energy-efficiency programme. In essence, a preliminary energy audit was conducted, by means of in-site visits, in order to determine the Significant Energy Uses (SEU) and gather the required necessary data. The SEUs in the yearly electricity consumption are presented in Table 1.

Table 1. SEUs in the case study Primary School

\begin{tabular}{|c|c|c|c|c|c|}
\hline Subsystem & Equipment & $\begin{array}{l}\text { Quantity } \\
\text { [pes.] }\end{array}$ & $\begin{array}{l}\text { Rated } \\
\text { Power } \\
{[\mathrm{kW}]}\end{array}$ & $\begin{array}{l}\text { Installed } \\
\text { Power } \\
{[\mathrm{kW}]}\end{array}$ & $\begin{array}{l}\text { Sub-System Weight } \\
\text { in the total Energy } \\
\text { Consumption [\%] }\end{array}$ \\
\hline HVAC & Air Conditioning Units & 30 & 2.5 & 75 & 35 \\
\hline \multirow{2}{*}{ Lighting } & CFL $4 \times 18 \mathrm{~W}$ fixtures & 640 & 0.072 & 46.08 & \multirow{2}{*}{23} \\
\hline & T8 CFL tubes & 120 & 0.036 & 4.32 & \\
\hline \multirow{6}{*}{ IT\&C } & $\mathrm{PC}$ & 82 & 0.12 & 9.84 & \multirow{6}{*}{19} \\
\hline & Laptop & 12 & 0.06 & 0.72 & \\
\hline & Monitors + TVs & 90 & 0.04 & 3.6 & \\
\hline & Printers & 12 & 1.5 & 18 & \\
\hline & $\begin{array}{l}\text { Modem, Routers, } \\
\text { Switches }\end{array}$ & - & 0.519 & 0.519 & \\
\hline & Paper Shredder & 4 & 2 & 8 & \\
\hline \multirow{5}{*}{ Appliances } & Dishwashing machine & 1 & 1.8 & 1.8 & \multirow{5}{*}{23} \\
\hline & Refrigerators & 2 & 0.186 & 0.372 & \\
\hline & Microwave oven & 4 & 3.5 & 14 & \\
\hline & Coffee filter & 2 & 2.1 & 4.2 & \\
\hline & Water Dispenser & 10 & 2.8 & 28 & \\
\hline \multicolumn{4}{|c|}{ Total } & 214.45 & 100 \\
\hline
\end{tabular}

Before considering the transition from a consumer to a prosumer, all the available and economically viable Energy Performance Improvement Actions (EPIA) must be implemented, in order to minimize and flatten the power curve of the energy boundary, thus minimizing the environmental impact of the boundary - Environmental Impact Reduction (EIR). Several EPIAs were analysed from a technic and economic point of view and the results are presented in Table 2. A conversion factor of 0.314 tonnes of $\mathrm{CO}_{2}$ equivalent per MWh was used.

Table 2. EPIA technic-economic analysis results

\begin{tabular}{|c|c|c|c|c|c|c|}
\hline \multirow{2}{*}{$\begin{array}{c}\text { EPIA } \\
\text { Type* }\end{array}$} & \multirow{2}{*}{ EPIA } & \multirow{2}{*}{$\begin{array}{c}\text { IC** } \\
\text { [EUR] }\end{array}$} & \multicolumn{3}{|c|}{ Annual Savings } & EIR \\
\cline { 5 - 7 } O & $\begin{array}{c}\text { Improving the energy } \\
\text { efficiency conduit of } \\
\text { personnel, energy } \\
\text { consumption accounting etc. }\end{array}$ & 0 & 2.05 & 0.176 & 1,024 & 0.64 \\
\hline LIC & $\begin{array}{c}\text { Installing temporization } \\
\text { systems for the IT\&C and } \\
\text { Appliances sub-systems }\end{array}$ & 307 & 13.45 & 1.16 & 1,156 & 4.02 \\
\hline HIC & $\begin{array}{c}\text { Replacing the 4x18W CFL } \\
* * * \text { fixtures with 30W } \\
\text { LED*** panels }\end{array}$ & 2,357 & 5.02 & 0.43 & 431 & 1.5 \\
\hline HIC & $\begin{array}{c}\text { Replacing the common } \\
\text { spaces CFL tubes with 8W } \\
\text { LED tubes }\end{array}$ & 196 & 1.89 & 0.163 & 163 & 0.566 \\
\hline
\end{tabular}

$* \mathrm{O}=$ Organizational EPIAs, LIC $=$ Low Investment Costs EPIAs, HIC $=$ High Investment Costs EPIAs, $* *$ IC $=$ Investment Costs $* * *$ CFL $=$ Compact Fluorescent Lights $/$ LED $=$ Light Emitting Diode

The analysis began by determining the monthly solar potential for all the regions in which the 726 standard gym halls are located, with a minimum result for Cluj-Napoca - 
$1.33 \mathrm{kWh} / \mathrm{m}^{2} /$ day in December and maximum value of Constanta $-6.57 \mathrm{kWh} / \mathrm{m}^{2} /$ day in July.

In order to determine the forecasted energy production for each school (1) was used:

$$
W_{\text {produced }}^{\text {monthly }}=A \cdot \mathrm{\eta}_{n} \cdot I_{\text {avg }} \cdot n_{\text {days }} \cdot C p\left[\frac{k W h}{\text { month }}\right]
$$

where $\mathrm{A}\left[\mathrm{m}^{2}\right]$ is the total surface of the PV system, $\eta_{\mathrm{n}}[\%]$ is the rated PV panel efficiency, $I_{\text {avg }}\left[\mathrm{kWh} / \mathrm{m}^{2} /\right.$ day] is the average daily irradiance, determined by using RetScreen software, $\mathrm{n}_{\text {days }}[-]$ is the number of days in the month and $\mathrm{Cp}[-]$ is the performance coefficient of the PV system. The performance coefficient of the PV system includes all types of power and energy losses of the system, out of which the most important are: Inverter losses - between $4 \%$ and $10 \%$, temperature generate PV cells losses - between $5 \%$ and $20 \%$, DC lines losses - between $1 \%$ and $3 \%$, AC line losses - between $1 \%$ and $3 \%$, Shading losses - between $0 \%$ and $80 \%$, Low-load losses in inverters - between $3 \%$ and $7 \%$, dust / snow / atmospheric pollution losses in PV cells - approximatively $2 \%$.

The forecasted production, respectively the power demand curve for Ploiesti's Primary School - the case study - is presented in Figure 2.

As it can be observed, due to the permanent use of the gym (Physical Education classes during the school year and Basketball / Martial Arts / Volley and Football classes throughout the year), the electricity consumption is higher than expected during the summer break (July-September).
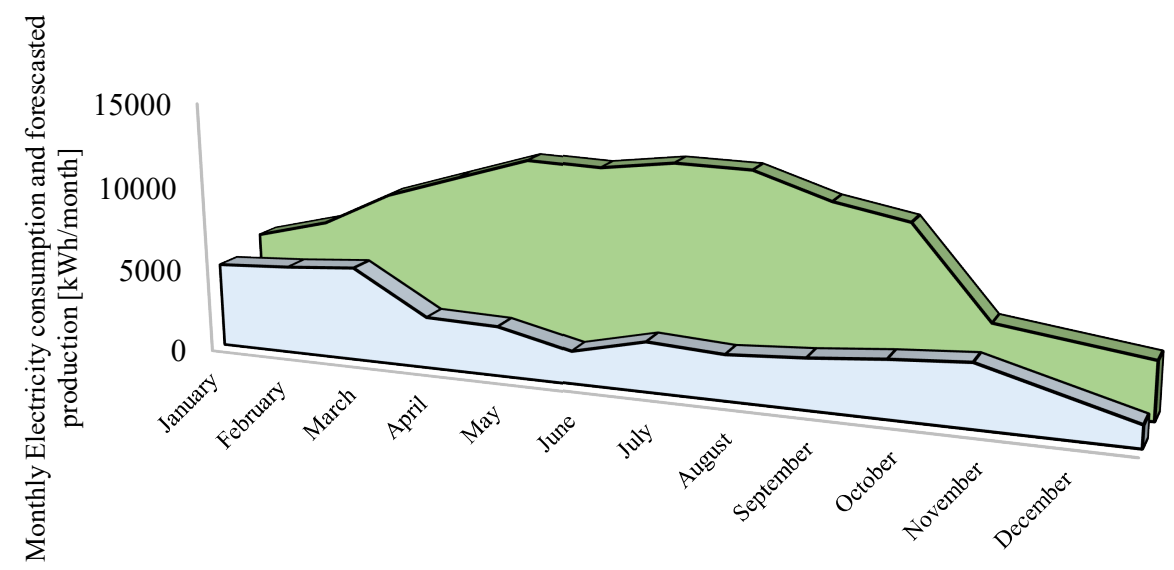

Fig. 2. Monthly electricity consumption (grey) and electricity production forecast (green) for Grigore Moisil Primary School in Ploiesti

In table 3 the forecasted energy production of Grigore Moisil's project and the extrapolated results for all the 726 schools are presented, as determined by using the RETScreen Expert software (https://www.nrcan.gc.ca/maps-tools-publications/tools/dataanalysis-software-modelling/retscreen/7465). 
Table 3. The monthly energy production forecast for Girgore Moisil and for all the 726 schools

\begin{tabular}{|c|c|c|}
\hline Month & $\begin{array}{c}\text { Ploiești Forecasted } \\
\text { Production [MWh] }\end{array}$ & $\begin{array}{c}\text { Global Forecasted Production } \\
{[\mathbf{M W h}]}\end{array}$ \\
\hline January & 5.79 & 3.552 \\
\hline February & 6.923 & 4.450 \\
\hline March & 8.977 & 6.083 \\
\hline April & 10.401 & 6.669 \\
\hline May & 11.768 & 7.876 \\
\hline June & 11.63 & 7.850 \\
\hline July & 12.226 & 8.313 \\
\hline August & 12.164 & 8.091 \\
\hline September & 10.723 & 6.513 \\
\hline October & 9.914 & 5.338 \\
\hline November & 4.636 & 3.360 \\
\hline December & 3.458 & 2.756 \\
\hline TOTAL & $\mathbf{1 0 5 . 1 5 2}$ & $\mathbf{6 8 , 1 0 3}$ \\
\hline
\end{tabular}

The main criterions used in the technic and economic analysis of the project were the Net Present Value - NPV (2), the Internal Rate of Return - IRR (3), the Simple Payback Period (4), determined by considering a variable annual net income and the Benefit - Cost Analysis - BCA (5). Levelized Cost of Electricity - LCOE (6) [5] was also determined, in order to compare the project with other relevant existing projects.

$$
N P V=\sum_{t=1}^{t s t} \frac{I_{t}-C_{t}}{(1+a)^{t}}-I C[E U R]
$$

where $t_{\text {tst }}$ is the analysis time-frame, in years, $I_{t}$ is the yearly income in the $t^{\text {th }}$ year, in EUR/year, $\mathrm{C}_{\mathrm{t}}$ are the yearly expenditures in the $\mathrm{t}^{\text {th }}$ year, in EUR/year, $a$ is the discount rate, in \%/year and IC is the investment cost, in EUR.

$$
N P V=\sum_{t=1}^{t s t} \frac{I_{t}-C_{t}}{(1+I R R)^{t}}=0[E U R]
$$

where the Investment Cost can be included in the yearly expenditures as a depreciation cost.

$$
\begin{gathered}
S P P=\frac{I C}{\frac{\sum_{i=1}^{t} I_{i}-C_{i}}{t}} \text { [years] } \\
B C A=\frac{I C}{N P V}[-] \\
L C O E=\sum_{t=1}^{n} \frac{\frac{I_{t}+C_{O \& M, t}+F_{C, t}}{(1+d r)^{t}}}{\frac{E_{t}}{(1+d r)^{t}}}[E U R / M W h]
\end{gathered}
$$

where the $\mathrm{C}_{\mathrm{O} \& \mathrm{M}}[\mathrm{EUR} / \mathrm{year}]$ is the annual Operation and Maintenance Cost, $\mathrm{F}_{\mathrm{C}}$ [EUR/year] are the annual Fuel Costs, $E_{t}$ is the annual generated power [MWh/year], $\operatorname{dr}[\%]$ is the 
degradation rate of the PV panels and $\mathrm{n}$ [years] is the average lifecycle of the project -25 years in this case [6], based on the standard PV panel Degradation graph.

The investment costs are divided into three categories:

$>$ PV Panel investment cost - starting from the average useful surface of the gym hall roof $-800 \mathrm{~m}^{2}$, and considering a PV panel with a surface of $1.97 \mathrm{~m}^{2}$, which includes the mounting distances, $203 \mathrm{PV}$ panels (with an installed power of 97.44 $\mathrm{kW}$ ) are considered, with an associated investment cost of approximatively 35,000 EUR;

$>$ Inverter investment cost - based on the PV panel installed power and the rated efficiency of the inverters (approximatively 94\%), in order to maximize the functioning times, fifteen $10 \mathrm{~kW}$ inverters were considered for installation, with an average price of $450 \mathrm{EUR} / \mathrm{pc}$. - a total investment cost of approximatively 6,700 EUR;

$>$ PV System Installation costs - considering the required materials (metallic profiles, electric cables, auxiliary components, distribution panels, a smart meter, insulation protection etc.) these costs range from between $5 \%$ to $10 \%$ of the total PV System cost - for this analysis a total installation cost of 4,000 EUR was considered.

The yearly Operation and Maintenance Costs were considered to be 500 EUR/year. The discount rate was considered $\mathrm{r}=5.6$ [\%/year] [7]. The average electricity acquisition price was considered $\mathrm{p}_{\mathrm{Wb}}=104 \mathrm{EUR} / \mathrm{MWh}$, for Ploiesti's Grigore Moisil Primary School. The average electricity selling price, as per [8], is $\mathrm{p}_{\mathrm{Ws}}=47 \mathrm{EUR} / \mathrm{MWh}$.

The analysis was conducted for a period of 25 years, as per the technical specifications of the PV cells, respectively of the power inverter units. A degradation factor of $0.6 \% /$ year was considered (with a minimum efficiency of $85 \%$ of the rated efficiency guaranteed throughout the 25 years analysis period).

The results obtained for Grigore Moisil Primary School and for all the other 725 primary schools (summed up as a global result, for the entire project) are presented in Table 4.

Table 4. The technic - economic analysis results

\begin{tabular}{|l|c|c|}
\hline \multicolumn{1}{|c|}{ Indicator } & Ploiessti & Nation-wide programme \\
\hline Net Present Value - NPV [EUR] & 44,665 & $27,640,207$ \\
\hline Internal Rate of Return - IRR [\%/year] & 14.88 & 13.61 \\
\hline Simple Payback Period - SPP [years] & 6.04 & 6.49 \\
\hline Benefit-Cost Analysis - BCA [-] & 1 & 0.85 \\
\hline Levelized Cost of Electricity - LCOE [EUR/MWh] & 98.12 & 119 \\
\hline
\end{tabular}

For a nation-wide programme the IRR, SPP and BCA indicators have worse values than for the Grigore Moisil Primary School project. These results are justified by the different solar potential of the various regions in which the analysed primary schools are located - as it can also be seen in Figure 3. 


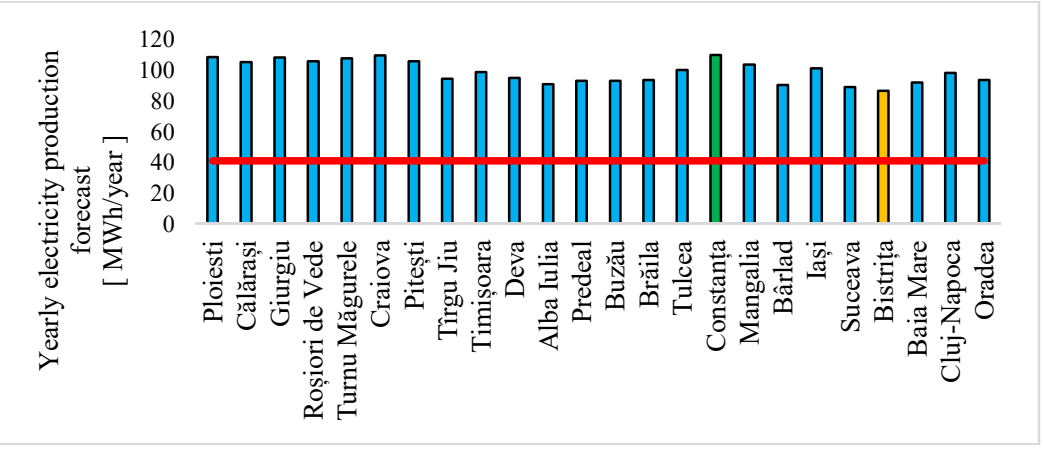

Fig. 3. Yearly electricity production forecast for the geographic areas in which the schools are situated with the average yearly electricity consumption for a standard primary school (red) and the most productive (green) respectively less productive (orange) areas.

\section{Project's Environmental Impact Reduction}

Based on the results presented in Section 2, the Environmental Impact (EI) of the case-study Primary School integration in a nation-wide programme of transition for Primary Schools from consumers to prosumers - Primary School Photovoltaic Initiative PSPI, in four scenarios: do nothing / EPIA only / PV only / PSPI is presented in Table 5.

Table 5. EI analysis results

\begin{tabular}{|l|c|c|c|c|}
\hline \multicolumn{1}{|c|}{ Scenario } & - & EI* Case Study & EI* PSPI & M.U. \\
\hline Do-Nothing & $(1)$ & 12.84 & 9,325 & [tonnes $\mathrm{CO}_{2 \mathrm{eq}} /$ year] \\
\hline EPIA only & $(2)$ & 7.32 & 5,315 & [tonnes $\mathrm{CO}_{2 \mathrm{eq}}$ /year] \\
\hline PV only & $(3)$ & -21.10 & $-12,060$ & [tonnes $\mathrm{CO}_{2 \mathrm{eq}} /$ year] \\
\hline PSPI & $(4)$ & -28.59 & $-17,375$ & [tonnes $\mathrm{CO}_{2 \mathrm{eq}}$ /year] \\
\hline Total Reduction & $\mathbf{( 1 ) - ( 4 )}$ & $\mathbf{4 1 . 4 3}$ & $\mathbf{2 6 , 7 0 0}$ & [tonnes $\mathbf{C O}_{2 \mathrm{eq}} /$ year] \\
\hline
\end{tabular}

*where the negative values represent the decrease of the Environmental Impact of the DSO, as a result of injecting the additional RES generated power into the power grid

PSPI's impact on the efficiency of the DSO's Power Grid was also taken into account. Based on the annual reports of the DSOs, the average Own Technological Consumption (OTC), which includes the Power and Energy losses and Commercial Losses is situated at $14 \%-15 \%$ of the transited low-voltage electricity [9]. The same reports state that the Power and Energy losses are of about $4 \%$, on average, which leads to an additional energy saving of up to 2,700 MWh/year, respectively $280,800 \mathrm{EUR} /$ year and 856 tonnes of $\mathrm{CO}_{2}$ equivalent per year. As it can be observed, the environmental impact of the project is significant. The PSPI reduces the national EI by 41.43 tonnes of $\mathrm{CO}_{2}$ equivalent per year for the case study Primary School (from the initial EI of 12.84 tonnes of CO2 equivalent per year to a negative EI of 28.59 tonnes of $\mathrm{CO} 2$ equivalent per year). At a global level, the PSPI would lead to a reduction of the environmental impact of up to 30,000 tonnes of $\mathrm{CO}_{2}$ equivalent per year - approximatively 637,500 tonnes of $\mathrm{CO}_{2}$ equivalent over the analysis period (25 years).

\section{Project development mechanisms}


The PSPI development should follow a clear and specific plan, in order to maximize it's technic, economic and environmental impact. Firstly, the Primary Schools involved should, with the help of Energy Services Companies - ESCOs, determine their baselines, via an Energy Management contract. Secondly, each Organisation should engage in a Complex Energy Auditing contract, in order to determine the optimal EPIA plan and evaluate the real technic and economic viability of installing a PV plant. Finally, the PSPI should finance the Primary Schools which satisfy a set of technic and economic viability targets.

The financing can be ensured by at least three accessible means. The first and easiest way of financing the PSPI is the Energy Performance Contracting. between ESCOs and the targeted Primary Schools. The PV project can be approached with a pay-back scheme similar to BOOT (Build-Own-Operate and Transfer) developments, in which ESCOs would get a return on investment (with a reasonable, project-wide, regulated profit margin) for the contract period, then the Primary School would get the ownership of the PV installation for free - a method which is fully accepted by the Romanian National Agency for Financial Administration (NAFA) [10]. If the energy efficiency improvement actions are approached in a different EPC - for example, a shared-energy savings contract, the Romanian Legislation should be modified so that the Public Administration can end the fiscal year with a variable result (different from the initial budgeted funds) - as the energy economy may be variable - thus the required energy related spending may also vary. At present, a Public Administration Entity must close the fiscal year with an economic indicator as close as possible to zero - any deviation (a decrease in energy consumption - thus a decrease in energy bills) leading to serious alterations of the next year available capital offered by the State Budget. The second option for financing the PSPI is by setting up a cooperation between the Ministry of Education and Research and the Ministry of Environment, Waters and Forests via it's Environment Fund Administration (EFA). At present, EFA finances with up to 20,000 RON/household (approximatively 4,200 EUR/household) up to 9,000 residential prosumer projects [11].The third option for financing the programme is by contracting a lease / credit from the EBRD, which has numerous PV installation projects financed and leased. A similar financing scheme is also available in Romania, the funding being covered by the Romanian Energy Efficiency Fund (REEF https://free.org.ro/) however, this option implies that the leased Organisation must co-finance the project with up to $20 \%$ of the total value - this might be less attractive for the Public Administration Entities. At present, in Romania, efforts are directed towards drawing an Energy Performance Contract. For over a year, the organization that represents some of the most representative ESCOs, ESCOROM (http://escorom.ro/eng/), in partnership with ANRE (Romanian National Energy Regulatory Authority) are struggling to issue a draft of an EPC. Such a model can give participants in project development confidence that the interest of all parties is protected.

\section{Conclusions and further research}

This paper presents the main technical and economic aspects that can describe a national programme to transform public consumers into prosumers. With the new legislation issued by the Romanian Parliament this is legally possible, and authors have investigated this opportunity and are presenting their results in this paper.

Starting from the case study, a concept that consists of implementing energy efficiency measures followed by the installation of PV panels was presented. Costs and benefits are more easily estimated, being given the fact that excess electricity is better managed over a longer period. The financial indicators for the case study are positive, with an IRR of almost $15 \%$ year and a payback period of around 6 years. The analysis of expanding such a 
project at a larger scale through a national programme, show financial indicators with smaller values but still attractive. This is given by the fact that the case study building is in southern Romania, with one of the best solar irradiances. LCOE is similar to the ASEAN [13] and other EU countries' [14] values of 130 EUR/MWh, respectively 107 EUR/MWh. The proposed PSPI could lead to an environmental impact reduction of approximatively 30,000 tonnes of $\mathrm{CO}_{2}$ equivalent per year, from the implementation in all the 726 Primary Schools.

While the value might seem irrelevant when compared to Romania's annual $\mathrm{CO}_{2}$ equivalent emissions, which are of approximatively 78.800.000 tonnes of $\mathrm{CO}_{2}$ equivalent per year, one must consider the fact that, in a Public / Local Administration, Primary Schools are only one of the multiple types of buildings that would be suitable for the transition from simple consumers to environmental friendly prosumers. For example, in Bucharest alone there are 419 state owned education-sector buildings (124 Kindergartens, 171 Primary Schools, 103 Secondary Schools, 2 Professional Schools, 1 Post-Secondary School, 7 children clubs, 7 sports clubs, 5 Art and Trade Schools), 86 state owned healthcare-sector buildings, 6 city halls, 6 NAFA buildings, 7 Courthouses, and around 200 other buildings for various other national or local institutions, with an additional, significantly higher, available sites in University Campuses. An important factor in the success of such a programme is the energy efficiency education of the Public Administration clerks. Ensuring an energy efficiency education for the personnel, corelated with properly applying the law [15],[16] for Public Authorities, will lead to a better understanding of the necessity and benefits of improving the EPIs and EIRs of each energy boundary owned and operated by the Romanian State.

As further research, other projects transitioning consumers to prosumers for the Public Administration should be assessed, such as waste to energy solutions, as photovoltaic systems are not applicable and viable from a technic and economic point of view to all state owned buildings, due to their geographic position, shading by other buildings, small available roof surface or because they are heritage buildings.

\section{References}

1. The Romanian Parliament, "Law no. 184/2018 for approving the Government Emergency Ordinance no. 24/2017 regarding the modification and updating of Law no. $220 / 2008$ for determining the incentive system for producing energy from renewable energy sources and the modification of other normative acts," Official Gazette, Part I, No. 635/20.07.2018.

2. Ministry of Energy, Economy and Business Environment, "2019 - 2030 Romania's Energy Strategy with the perspective of 2050," 2019.

3. Nikolina Sajn, "Briefing - Electricity "Prosumers"," European Union's Research Service, 2016.

4. Lenhart, J., van Vliet, B. \& Mol, A., "New roles for local authorities in a time of climate change: the Rotterdam Energy Approach and Planning as a case of urban symbiosis. Journal of Cleaner Production,” vol. 107, pp.593- 601, 2015.

5. Aishwarya S. Mundada. Kunal K. Shah. Joshua. M. Pearce. "Levelized Cost of Electricity for Solar Photovoltaic. Battery and Cogen Hybrid Systems." Renewable and Sustainable Energy Reviews 57. 2016.

6. The Romanian Government, "Decision no. 2139/30.10.2004 for approving the normal period of use for capital goods," Oficial Gazette, Part I, No. 46/13.01.2005.

7. Public Procurement National Agency, "Order no. 2717/318/2018 for the revision of the discount rate," 2019. 
8. Romanian National Energy Regulatory Authority, "Order no. 227/2018 regarding the approval of the framework contract for buying and selling electricity produced by the prosumers which own a renewable sources power generation installation of up to 27 $\mathrm{kW}$ per site and to modify previous regulations of the electricity sector," Official Gazette, Part 1, No. 1114/28.12.2018.

9. https://www.anre.ro/ro/energie-electrica/legislatie/documente-de-discutieee/metodologii-proceduri-tarifare/ [accessed in January 2020]

10. The Romanian Parliament, "Law no. 50/2019 regarding the State Budget of Romania," Official Gazette, Part I, No. 209/15.03.2020.

11. Environment Fund Administration, "Photovoltaic Green House Programme," 2019.

12. The Emission Database for Global Atmospheric Research (EDGAR), https://edgar.jrc.ec.europa.eu/ [accessed in January 2020].

13. European Technology and Innovation Platform, "PhotoVoltaic," PV Manufacturing in Europe Conference, 2017.

14. Md Abdullah AL MATIN, Shutaro TAKEDA, Yugo TANAKA, Shigeki SAKURAI and Tetsuo TEZUKA, "LCOE Analysis for Grid-Connected PV Systems of Utility Scale Across Selected ASEAN Countries," ERIA Discussion Paper Series no. 305, ERIA-DP-2019-19, 2019.

15. The Romanian Parliament, "The Energy Efficiency Law no. 121/2014," Official Gazette, Part I, No. 574 from 01.08.2014.

16. The Romanian Parliament, "Law no. 160/2016 for modifying and updating the Energy Efficiency Law no. 121/2014,” Official Gazette, Part I, No. 562 from 26.07.2016. 